\title{
Nitrifying bacteria mediate aerobic ammonia oxidation and urea hydrolysis within the Grand River
}

\author{
Puntipar Sonthiphand, Josh D. Neufeld* \\ Department of Biology, University of Waterloo, 200 University Avenue West, Waterloo, Ontario N2L 3G1, Canada
}

\begin{abstract}
Ammonia oxidation is an important process for decreasing ammonia concentrations in wastewater-impacted rivers. Ammonia-oxidizing bacteria (AOB) and archaea (AOA) are responsible for ammonia oxidation, which is the first step of the nitrification process. Nitrification and urea hydrolysis were monitored in sediment and water column samples in the Grand River (Ontario), and nitrification inhibitors (allylthiourea and 2-phenyl-4,4,5,5-tetramethylimidazoline1-oxyl 3-oxide) helped identify the relative contributions of AOA and AOB to ammonia oxidation. Despite the presence of AOA, our results implicated AOB as the dominant contributors to ammonia oxidation, both directly and in association with urea hydrolysis.
\end{abstract}

KEY WORDS: Nitrification activity - Ammonia oxidizing bacteria $\cdot$ Ammonia oxidizing archaea PTIO $\cdot$ ATU

Resale or republication not permitted without written consent of the publisher

\section{INTRODUCTION}

Nitrification is composed of 2 oxidative processes. The first step is ammonia oxidation to nitrite under oxic conditions, which is mediated by ammoniaoxidizing bacteria (AOB) and archaea (AOA). This process is followed by nitrite oxidation to nitrate, which is mediated by aerobic nitrite-oxidizing bacteria (NOB). High ammonia loads in impacted rivers adversely affect drinking water quality, aquatic life, and ecosystem health. Ammonia oxidation is an important process, removing ammonia from impacted freshwater environments (Sonthiphand et al. 2013). For many decades, AOB were believed to be the sole microorganisms responsible for ammonia oxidation, until the discovery and isolation of AOA (Könneke et al. 2005). Although both $\mathrm{AOB}$ and $\mathrm{AOA}$ have the ability to oxidize ammonia, each has unique physiological properties (i.e. enzyme structure, intermediates, and substrate affinity; Zhalnina et al. 2012), evidenced by differential sensitivities to nitrification inhibitors. Distinct ammoniacal N sources might also differentially affect the relative environmental contributions of AOB and AOA. Previous studies have demonstrated that $\mathrm{AOB}$ are more abundant and active than AOA in inorganic fertilized soils (Jia \& Conrad 2009, Xia et al. 2011). Systems treated with organic fertilizer (i.e. urea and animal urine substrate) are also dominated by AOB (Di et al. 2009, O'Callaghan et al. 2010, Di \& Cameron 2011). However, AOA utilize ammonia from the mineralization of organic substances and outnumber AOB in soil microcosms (Gubry-Rangin et al. 2010, Zhang et al. 2010).

Ammonia monooxygenase (AMO) is a key enzyme for ammonia oxidation by both AOA and AOB. However, urease is an optional enzyme, discovered in some AOB and AOA species, that is used to hydrolyse urea as an alternative $\mathrm{N}$ energy source. Distinct ammonia sources might govern the ratio of environmental AOB and AOA due to differences in urease activity. Urease genes have been reported for Nitrosomonas ureae, $N$. nitrosa, $N$. oligotropha, N. marina, and N. aestuarii (Pommerening-Röser \& Koops 2005). Although only 2 AOA pure cultures are available, genome analysis has revealed the presence of a urease gene within 'Candidatus Cenarchaeum symbiosum' (Hallam et al. 2006), Nitrososphaera viennensis 
(Tourna et al. 2011), 'Candidatus Nitrososphaera gargensis' (Spang et al. 2012), and 'Candidatus Nitrosopumilus salaria' (Mosier et al. 2012). Consequently, particular $\mathrm{AOB}$ and AOA species may generate ammonia for aerobic respiration from urea hydrolysis in situ.

Many studies have investigated nitrification activity in freshwater environments (e.g. Strauss \& Lamberti 2000, Kemp \& Dodds 2002) and the relative ammonia oxidation activities of AOB and AOA using differential inhibitors in terrestrial environments (e.g. Di et al. 2009, Taylor et al. 2010). However, no study has reported on nitrification activities with differential inhibitors to determine the relative contributions of $\mathrm{AOB}$ and $\mathrm{AOA}$ in freshwater environments. Allylthiourea (ATU) inhibits the first step of nitrification by chelating copper from the AMO active site (Bédard \& Knowles 1989). AOB and AOA respond differently to ATU due to differences in inhibition thresholds and amino acids in the active site of AMO (Lehtovirta-Morley et al. 2013, Shen et al. 2013). AOB appear to be more sensitive to ATU than AOA in soil (Taylor et al. 2010) and marine (Santoro \& Casciotti 2011) environments. In a study of an AOA-enriched agricultural soil, 'Candidatus Nitrosoarchaeum koreensis' was not inhibited by ATU, whereas ATU at low concentrations inhibited Nitrosomonas europaea (Jung et al. 2011). At the same concentration, Nitrosospira multiformis was more sensitive to ATU than $N$. viennensis (Shen et al. 2013). PTIO (2-phenyl-4,4,5,5-tetramethylimidazoline-1-oxyl 3-oxide) inhibits ammonia oxidation by acting as a nitric oxide (NO) scavenger. NO is a likely intermediate of AOA ammonia oxidation, but not AOB ammonia oxidation (Walker et al. 2010). PTIO can effectively inhibit $N$. viennensis without affecting N. multiformis (Shen et al. 2013). This study represents the first application of PTIO to environmental sample incubations.

The objectives of this study were to assess in vitro ammonia oxidation and urea hydrolysis to reveal ammoniaoxidizer dynamics within the largest watershed in Southern Ontario, the Grand River. This activity-based study follows on from our initial molecular assessment of AOA, AOB and anaerobic ammonia-oxidizing (anammox) bacteria in Grand River sediment and water columns, and a strong enrichment of AOB within wastewater treatment plant (WWTP) effluent plumes (Sonthiphand et al. 2013). We tested the hypothesis that $\mathrm{AOB}$ dominate ammonia oxidation within the Grand River, which would be consistent with our initial observation that AOB became enriched following prolonged high-ammonia incubations. This is the first study to combine nitrification activities and urea hydrolysis measurements with inhibitors to differentiate between $\mathrm{AOB}$ and $\mathrm{AOA}$ activities within a freshwater environment.

\section{MATERIALS AND METHODS}

\section{Sample collection}

The Grand River watershed is the largest catchment in Southern Ontario and much impacted by human activities. In this study, a central portion of the Grand River was used as an example of a watershed impacted by wastewater effluent. Downstream and upstream sampling sites of wastewater effluent represented sites of high and low impact by wastewater effluent, respectively. Sediment and water samples were collected approximately $180 \mathrm{~m}$ downstream from an ammonia-rich wastewater discharge pipeline from a municipal wastewater treatment plant in Waterloo, Ontario, Canada on 11 June 2013. Due to high sample heterogeneity, sediment samples were collected at 5 random locations using a plastic core tube and pooled on site. Water samples were well mixed at the sampling site and were collected using a $500 \mathrm{ml}$ plastic container. All samples were kept on ice during transport to the lab. Conductivity, $\mathrm{pH}$, and dissolved oxygen were measured on site (Table 1). Follow-up samples were taken on 31 July 2013. Upstream samples, as well as downstream samples, were included in the follow-up study for comparison. Upstream sediment and water samples were collected approximately $390 \mathrm{~m}$ upstream from the pipeline effluent using the methods described above.

Table 1. Downstream and upstream water chemistry data. NA = not available; $\mathrm{BDL}=$ below detection limit; $\mathrm{pH}$ (late-July) was analyzed in the lab

\begin{tabular}{|c|c|c|c|}
\hline & \multirow{2}{*}{$\begin{array}{l}\text { Mid-June } \\
\text { Downstream } \\
\text { water }\end{array}$} & \multicolumn{2}{|c|}{ Late-July } \\
\hline & & $\begin{array}{l}\text { Upstream } \\
\text { water }\end{array}$ & $\begin{array}{l}\text { Downstream } \\
\text { water }\end{array}$ \\
\hline Conductivity $(\mu \mathrm{S})$ & 1031 & 480 & 1019 \\
\hline $\mathrm{pH}$ & 7.5 & 8.0 & 7.9 \\
\hline Dissolved oxygen $\left(\mathrm{mg} \mathrm{l}^{-1}\right)$ & 8.23 & NA & NA \\
\hline $\mathrm{N}-\left[\mathrm{NH}_{3}+\mathrm{NH}_{4}^{+}\right](\mu \mathrm{M})$ & 560.46 & BDL & 571.98 \\
\hline $\mathrm{N}-\left[\mathrm{NO}_{2}^{-}+\mathrm{NO}_{3}^{-}\right](\mu \mathrm{M})$ & 147.20 & 151.29 & 166.55 \\
\hline $\mathrm{N}-\left[\mathrm{NO}_{2}^{-}\right](\mu \mathrm{M})$ & BDL & BDL & 20.62 \\
\hline N-urea $(\mu \mathrm{M})$ & BDL & 239.89 & BDL \\
\hline
\end{tabular}




\section{In vitro nitrification activity}

For each sediment treatment replicate, $1 \mathrm{~g}$ of pooled downstream sediment was added to $10 \mathrm{ml}$ of modified inorganic freshwater media (FWM; Tourna et al. 2011). The modified FWM, without HEPES buffer, was adjusted to $\mathrm{pH}$ 7.5. Samples were inoculated with an initial total ammonia $\left(\mathrm{NH}_{3}+\mathrm{NH}_{4}{ }^{+}\right)$concentration of $600 \mu \mathrm{M}$. There were 3 treatments: without an inhibitor, with ATU (10 or $100 \mu \mathrm{M})$, and with PTIO $(100 \mu \mathrm{M})$. In addition to sediment slurries, $10 \mathrm{ml}$ of downstream water samples were added to test tubes, without FWM. Ammonia, ATU, and PTIO were added to each tube at the same concentrations as those for the sediment set. Negative controls were conducted with FWM (without sample inoculation) for all treatments. All treatments and negative controls were conducted in triplicate and statically incubated in the dark at room temperature $\left(\sim 25^{\circ} \mathrm{C}\right)$ for $14 \mathrm{~d}$. The incubations were suspended manually once a day. Both sediment and water column upstream samples were treated as described for the downstream samples. For water chemistry measurements, $1 \mathrm{ml}$ of each sample was collected on Days $0,1,3,5$, 7,11 , and 14 . Nitrification rates were estimated based on linear regression of $\mathrm{NO}_{2}{ }^{-}+\mathrm{NO}_{3}{ }^{-}$concentrations between Days 3 and 7 . We used a $t$-test to identify significant differences in $\mathrm{NO}_{2}{ }^{-}+\mathrm{NO}_{3}{ }^{-}$productions between any 2 treatments (using Excel software, Microsoft). The null hypothesis was that the $\mathrm{NO}_{2}{ }^{-}+$ $\mathrm{NO}_{3}{ }^{-}$productions between 2 treatments were the same. If the $p$-value was $\leq 0.05$, the null hypothesis was rejected.

\section{In vitro urea hydrolysis}

Urea hydrolysis was tested in parallel to in vitro nitrification rate incubations. Both downstream and upstream sediment and water samples, including negative controls, were incubated with differential inhibitors, using the same treatments and conditions as those described above for nitrification activity. Urea-N (600 $\mu \mathrm{M})$ was added to the modified FWM instead of ammonia. All samples were monitored at the same 7 time points.

\section{Chemical analyses}

Ammonia concentrations were measured by a fluorometric technique according to an established protocol (Poulin \& Pelletier 2007). Nitrite and nitrate measurements were conducted by a colorimetric assay (Miranda et al. 2001). Briefly, nitrate was reduced to nitrite $\mathrm{N}-\left[\mathrm{NO}_{2}{ }^{-}+\mathrm{NO}_{3}{ }^{-}\right]$by $\mathrm{VCl}_{3}$. Consequently, the concentrations of $\mathrm{N}-\mathrm{NO}_{2}{ }^{-}$and $\mathrm{N}-\left[\mathrm{NO}_{2}{ }^{-}+\mathrm{NO}_{3}^{-}\right]$can be measured using the same method. Urea was measured by a previously published protocol (Zawada et al. 2009), with analysis at $450 \mathrm{~nm}$ instead of $430 \mathrm{~nm}$. All ammonia, urea, and N-oxide analyses were performed on a FilterMax F5 Multi-Mode Microplate Reader (Molecular Devices).

\section{DNA extraction and quantitative real-time PCR}

DNA was extracted from sediment and water samples using the PowerSoil DNA kit (Mo Bio Laboratories) and PowerWater Sterivex DNA Isolation Kit (Mo Bio Laboratories), respectively, following the manufacturer's protocols. All extracts were analyzed for DNA concentration using a NanoDrop spectrophotometer ND-100 (Thermo Fisher Scientific) before being diluted to $5 \mathrm{ng} \mathrm{l}^{-1}$ to serve as template for quantitative PCR (qPCR). AOB and AOA 16S rRNA genes were quantified using primers NitA (Voytek \& Ward 1995) and CTO654r (Kowalchuk et al. 1997) and primers 771F and 957R (Ochsenreiter et al. 2003), respectively. The qPCR master mix contained $5 \mu \mathrm{l}$ of SsoAdvanced SYBR Green Supermix (Bio-Rad), $0.03 \mu$ of each primer $(100 \mu \mathrm{M}), 0.02 \mu \mathrm{l}$ of bovine serum albumin $(10 \mathrm{mg}$ $\left.\mathrm{ml}^{-1}\right)$, and $1 \mu \mathrm{l}$ of genomic DNA template $\left(5 \mathrm{ng}^{-1}\right)$ in a total volume of $10 \mu \mathrm{l}$. All amplifications were conducted in duplicate on a CFX96 real-time system (Bio-Rad). A qPCR thermal cycle started with an initial denaturation at $98^{\circ} \mathrm{C}$ for $2 \mathrm{~min}$, followed by 35 cycles of $98^{\circ} \mathrm{C}$ for $5 \mathrm{~s}$, annealing at $57^{\circ} \mathrm{C}$ and $55^{\circ} \mathrm{C}$ for $\mathrm{AOB}$ and AOA $16 \mathrm{~S}$ rRNA genes, respectively, for $30 \mathrm{~s}$, and $72^{\circ} \mathrm{C}$ for $30 \mathrm{~s}$. After each cycle, plate reads were added at $81^{\circ} \mathrm{C}$ and $80^{\circ} \mathrm{C}$ for $\mathrm{AOB}$ and AOA 16S rRNA genes, respectively. Plasmids containing $\mathrm{AOB}$ and AOA 16S rRNA gene fragments were amplified, purified by a MinElute kit (Qiagen) and quantified by the NanoDrop Spectrophotometer ND-100 before being diluted for qPCR standards. Ten-fold serial dilutions were performed in the range of $10^{1}$ to $10^{7}$ copies to create a standard curve for each gene. The standard curves showed an efficiency of $80.8 \%\left(\mathrm{R}^{2}=0.99\right)$ and $82.6 \%\left(\mathrm{R}^{2}=0.99\right)$ for $\mathrm{AOB}$ and AOA $16 \mathrm{~S}$ rRNA genes, respectively. The specificity of amplification was verified by melt curve analysis and agarose gel electrophoresis. 


\section{RESULTS}

\section{Activity of aerobic ammonia oxidizers within impacted river}

Downstream sediment and water samples were collected in mid-June. Follow-up samples were collected in late-July. Differential inhibitors were used to distinguish between $\mathrm{AOB}$ and AOA activities. ATU and PTIO at specific concentrations were used to selectively inhibit $\mathrm{AOB}$ and $\mathrm{AOA}$, respectively. Two ATU concentrations $(10 \mu \mathrm{M}$ and $100 \mu \mathrm{M})$ were used in the follow-up experiment for comparison. The results of ATU-treated samples under both conditions (10 and $100 \mu \mathrm{M}$ ) were similar (data not shown).

For mid-June downstream sample sediment incubations, ammonia concentrations decreased to below detection limits by Day 10 , and $\mathrm{NO}_{2}{ }^{-}+\mathrm{NO}_{3}{ }^{-}$production increased to $\sim 600 \mu \mathrm{M}$ by Day 14 , indicating active ammonia oxidation (Fig. $1 \mathrm{~A}$ ). $\mathrm{NO}_{2}^{-}$did not accumulate, presumably due to active nitrite-oxidizing bacteria (NOB) in the downstream pipeline effluent (Mußmann et al. 2013). Ammonia concentrations decreased gradually in downstream sediment incubations with PTIO (depleted by Day 10) and $\mathrm{NO}_{2}{ }^{-}+\mathrm{NO}_{3}{ }^{-}$both accumulated between Days 5 and 14 (Fig. 1B). $\mathrm{NO}_{2}{ }^{-}+$ $\mathrm{NO}_{3}{ }^{-}$productions in unamended and PTIO treatments were not significantly different $(p>0.05)$. Nitrification rates in unamended and PTIO treatments were 83.3 $\left(\mathrm{R}^{2}=0.8\right)$ and $101.7\left(\mathrm{R}^{2}=0.8\right) \mu \mathrm{MN}-\left[\mathrm{NO}_{2}{ }^{-}+\mathrm{NO}_{3}{ }^{-}\right] \mathrm{g}^{-1}$ sediment $\mathrm{d}^{-1}$, respectively. In contrast, $100 \mu \mathrm{M}$ ATU inhibited all $\mathrm{NO}_{2}{ }^{-}+\mathrm{NO}_{3}{ }^{-}$production and ammonia depletion within downstream sediments (Fig. 1C).

The initial Day 0 ammonia concentration for downstream water samples was higher than for sediment sample incubations because there were 2 ammonia sources for the water samples: natural ammonia in the river water (Table 1) and experimental ammonia addition. Ammonia was completely depleted by Day 7 in downstream water samples without an inhibitor and with PTIO; $\mathrm{NO}_{2}{ }^{-}+\mathrm{NO}_{3}{ }^{-}$production increased between Days 5 and 7 , then was relatively unchanged until Day 14 (Fig. 1D,E). $\mathrm{NO}_{2}{ }^{-}+\mathrm{NO}_{3}{ }^{-}$productions in these 2 treatments were not significantly different $(p>0.05)$. $\mathrm{NO}_{2}{ }^{-}$concentrations were oxidized to below the detection limits for incubations without an inhibitor (Fig. 1D), but remained present in incubations with PTIO (Fig. 1E). This observation corresponded with other downstream water column samples; $\mathrm{NO}_{2}^{-}$concentrations eventually decreased to below the detection limit (Figs. 2D, 3D, \& 4D), but remained undepleted in all PTIO-treated downstream water samples (Figs. 2E, 3E, \& 4E), implying that PTIO inhibited in vitro $\mathrm{NO}_{2}{ }^{-}$oxidation. Downstream water samples amended with $100 \mu \mathrm{M}$ ATU showed little evidence of ammonia oxidation (Fig. 1F). Nitrification rates of downstream water samples with no inhibitor, with PTIO, and with ATU additions were $32.3\left(\mathrm{R}^{2}=0.9\right), 36.2\left(\mathrm{R}^{2}=0.7\right), 1.8\left(\mathrm{R}^{2}=0.06\right) \mu \mathrm{M}$ $\left[\mathrm{NO}_{2}{ }^{-}+\mathrm{NO}_{3}^{-}\right] \mathrm{ml}^{-1}$ water $\mathrm{d}^{-1}$, respectively.

Notably, late-July downstream sediment samples depleted ammonia more slowly than June samples, only depleting the added ammonia by the last incubation day (Day 14; Fig. 2A,B) compared with nearly complete depletion by Day 10 for mid-June samples (Fig. 1A,B).

The increasing ammonia during the first 2 to 5 days from downstream sediments (Fig. 2A-C) was possibly from mineralization of organic matter and/or dissimilatory nitrate reduction to ammonium. Ammonia gradually decreased throughout the incubation period, although we observed very little $\mathrm{NO}_{2}{ }^{-}+\mathrm{NO}_{3}{ }^{-}$accumulation in both unamended and PTIO-supplemented treatments. Possible reasons for this observation might be that other $\mathrm{N}$-transformation processes occurred within an oxic-anoxic interface within these static sediment incubations. Anammox bacteria oxidize ammonia by using nitrite as an electron acceptor to produce $\mathrm{N}_{2}$ gas, and we have previously observed molecular evidence of anammox bacteria at these same sites (Sonthiphand et al. 2013). Denitrifiers transform $\mathrm{NO}_{3}{ }^{-}$to $\mathrm{N}_{2}$ gas and other $\mathrm{N}$-oxide intermediates (Thamdrup 2012). Other than microbial processes, sediments might adsorb ammonia from FWM as an exchangeable ion on sediment surfaces (Simon \& Kennedy 1987, Rysgaard et al. 1999). Nitrification rates of unamended and PTIO treatments were 43.0 $\left(\mathrm{R}^{2}=0.9\right)$ and $74.7\left(\mathrm{R}^{2}=0.8\right) \mu \mathrm{MN}-\left[\mathrm{NO}_{2}{ }^{-}+\mathrm{NO}_{3}{ }^{-}\right] \mathrm{g}^{-1}$ sediment $\mathrm{d}^{-1}$, respectively. Consistent with our midJune samples, downstream sediment samples with ATU showed no nitrification activity (Fig. 2C).

For late-July downstream water samples, ammonia concentrations were undetectable by Day 10 (Fig. 2D,E), which represents a longer period than for the mid-June samples (Fig. 1D,E). Total $\mathrm{NO}_{2}{ }^{-}+\mathrm{NO}_{3}{ }^{-}$ production increased from Days 3 to $7 ; \mathrm{NO}_{2}{ }^{-}$subsequently remained stable in the presence of PTIO only (Fig. 2D,E). $\mathrm{NO}_{2}{ }^{-}+\mathrm{NO}_{3}{ }^{-}$productions for these 2 treatments showed no significant difference $(p>0.05)$. As with mid-June samples, late-July downstream water with ATU showed little ammonia depletion and $\mathrm{NO}_{2}{ }^{-}$ $+\mathrm{NO}_{3}{ }^{-}$production (Fig. 2F). Nitrification rates of unamended, PTIO-treated, and ATU-treated downstream water samples were $25.1\left(R^{2}=1\right), 26.19\left(R^{2}=1\right)$, and $5.8\left(\mathrm{R}^{2}=0.9\right) \mu \mathrm{MN}-\left[\mathrm{NO}_{2}{ }^{-}+\mathrm{NO}_{3}{ }^{-}\right] \mathrm{ml}^{-1}$ water $\mathrm{d}^{-1}$, respectively. All negative controls showed no microbial activity (data not shown). 
Mid-June downstream sediment
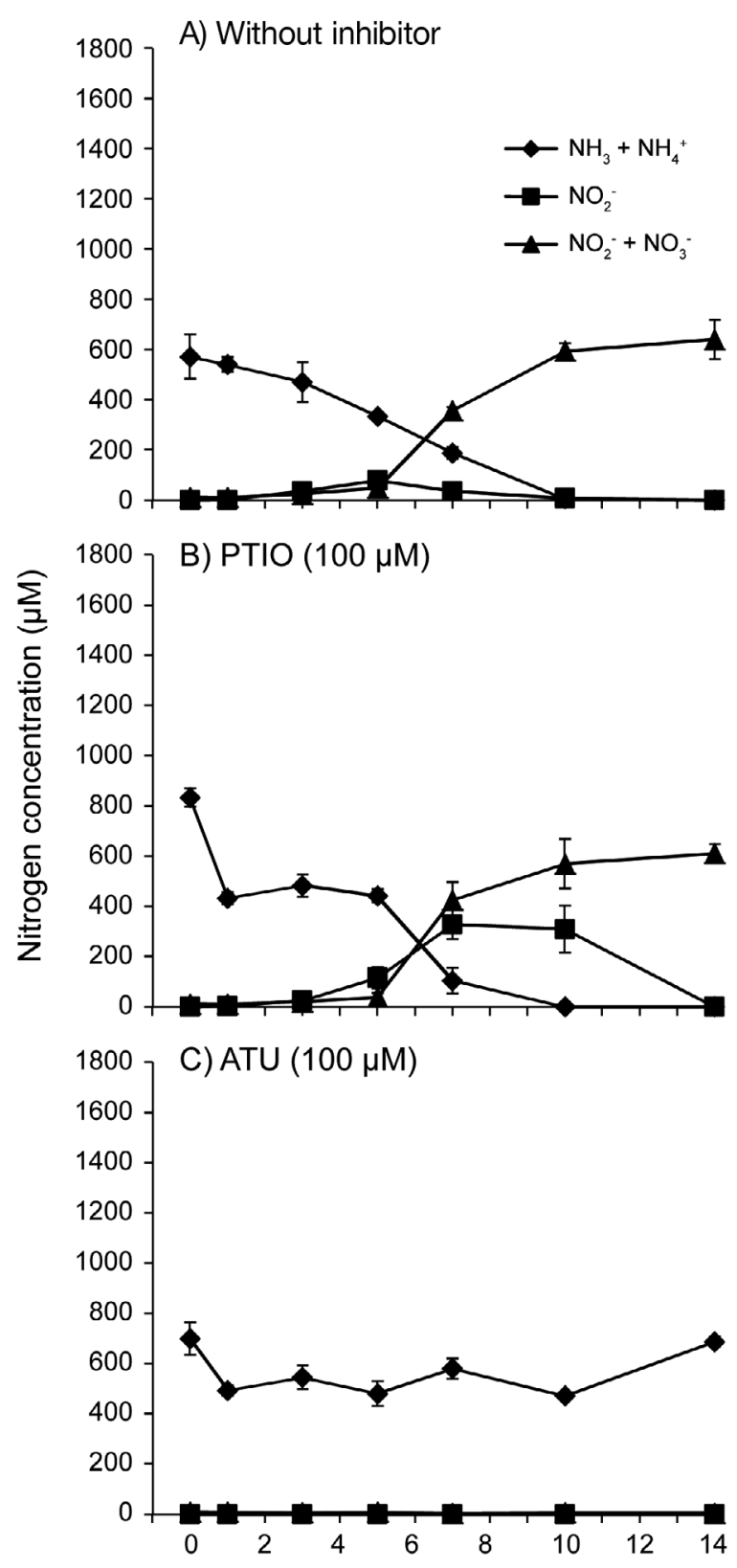

Mid-June downstream water

D) Without inhibitor

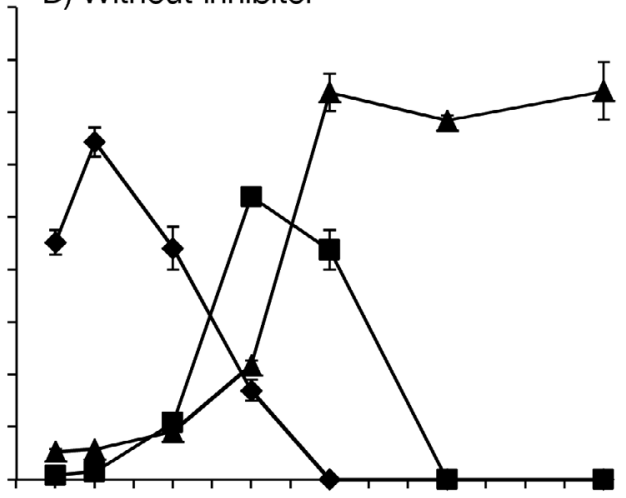

E) PTIO $(100 \mu \mathrm{M})$

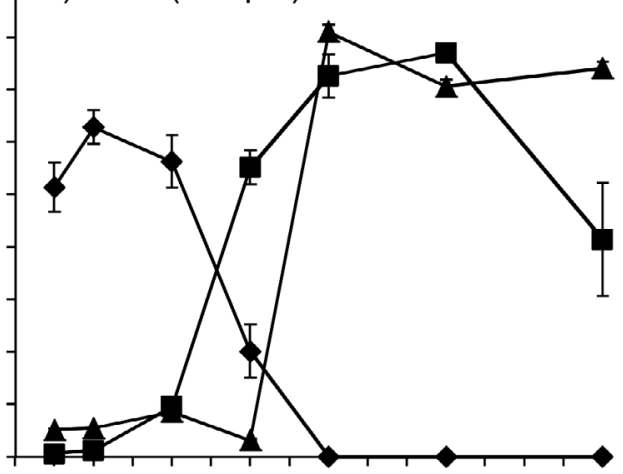

F) ATU $(100 \mu \mathrm{M})$
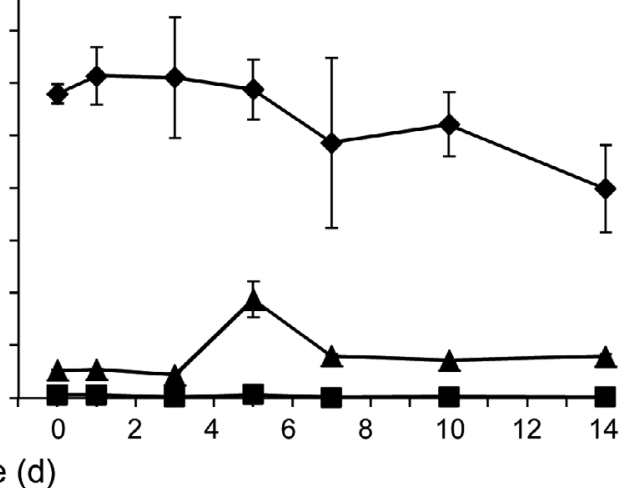

Fig. 1. Nitrification activity of mid-June downstream sediment and water samples with the 3 treatments: $(A, D)$ without an inhibitor, (B, E) with PTIO (2-phenyl-4,4,5,5-tetramethylimidazoline-1-oxyl 3-oxide), and (C, F) with ATU (allylthiourea). The concentrations of all compounds were reported as $\mathrm{N}-\left[\mathrm{NH}_{3}+\mathrm{NH}_{4}{ }^{+}\right], \mathrm{N}-\mathrm{NO}_{2}{ }^{-}$, and $\mathrm{N}-\left[\mathrm{NO}_{2}{ }^{-}+\mathrm{NO}_{3}{ }^{-}\right] \mu \mathrm{M}$. Error bars represent standard deviation of biological triplicates. Note that the concentrations of $\mathrm{N}_{-} \mathrm{NO}_{2}^{-}$and $\mathrm{N}-\left[\mathrm{NO}_{2}^{-}+\mathrm{NO}_{3}^{-}\right]$were below the detection limits (panel C)

Upstream samples were included as a background site where ammonia concentration was below the detection limit (Table 1). Both sediment and water upstream samples were analyzed only in the followup study (Fig. S1 in the Supplement at www.int-res. com/articles/suppl/a073p151_supp.pdf). Nitrification rates of upstream sediment samples with no inhibi- tor and with PTIO were $21.3\left(\mathrm{R}^{2}=0.9 ;\right.$ Fig. S1A) and $17.1\left(\mathrm{R}^{2}=0.9\right.$; Fig. S1B) $\mu \mathrm{M} \mathrm{N}-\left[\mathrm{NO}_{2}{ }^{-}+\mathrm{NO}_{3}{ }^{-}\right] \mathrm{g}^{-1}$ sediment $\mathrm{d}^{-1}$, respectively. As with downstream sediments, ATU completely inhibited nitrification activity in upstream sediments (Fig. S1C). Upstream water showed no nitrification activity in all treatments (Fig. S1D-F). 


\section{Late-July downstream sediment}

A) Without inhibitor
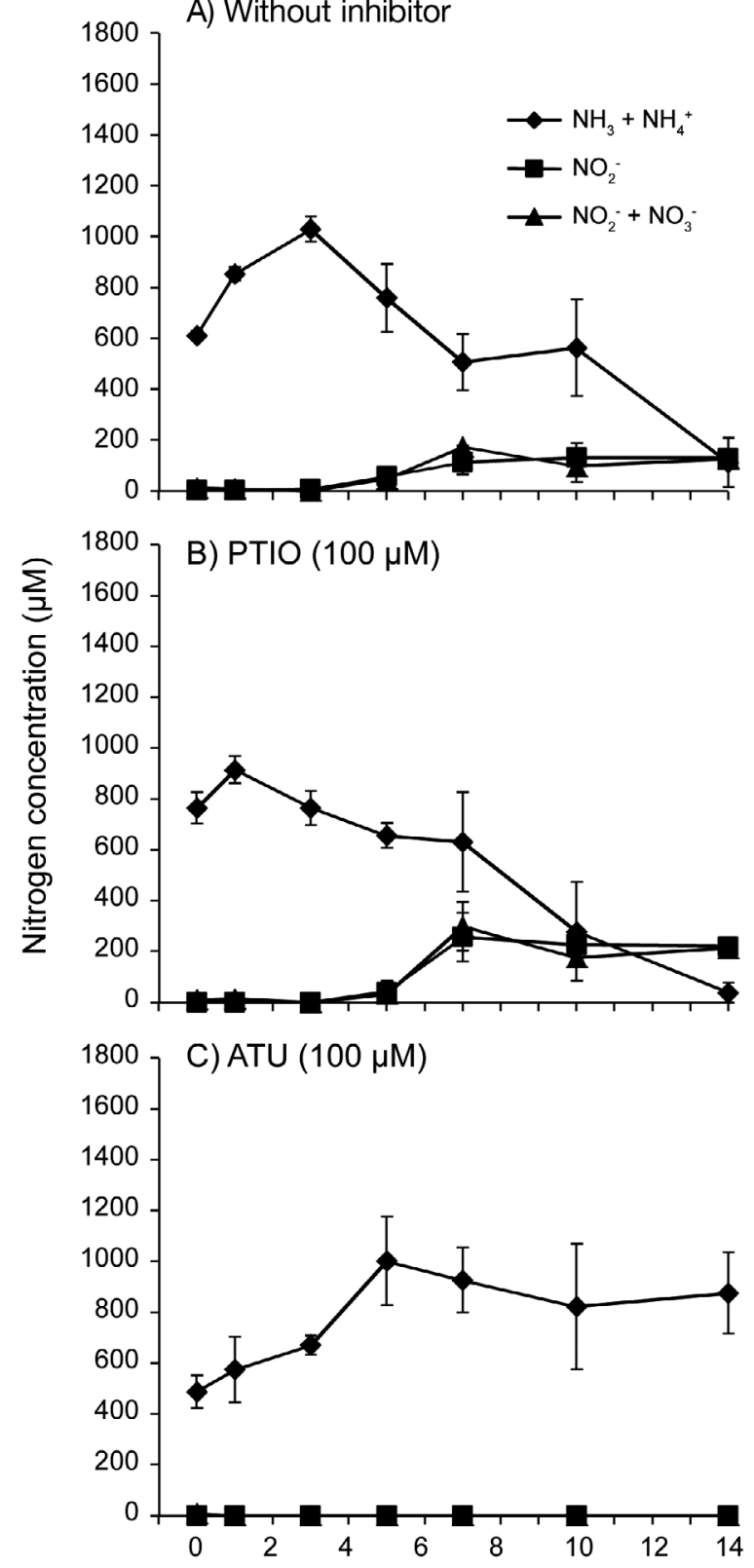

\section{Late-July downstream water}

D) Without inhibitor

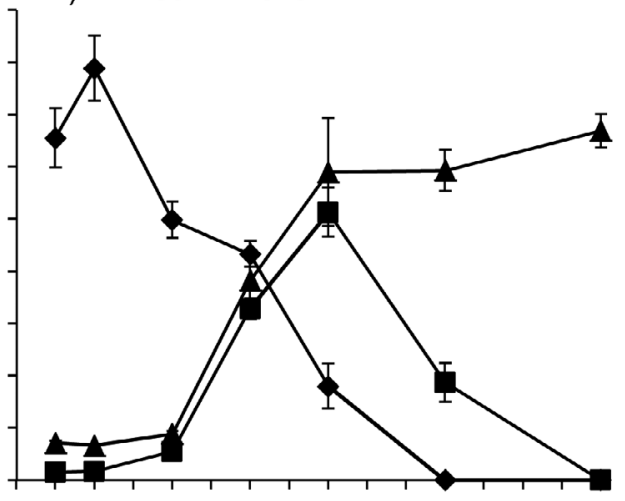

E) PTIO $(100 \mu \mathrm{M})$

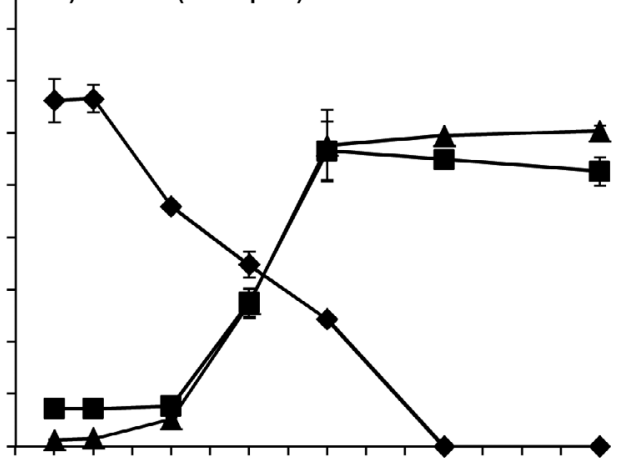

F) ATU $(100 \mu \mathrm{M})$

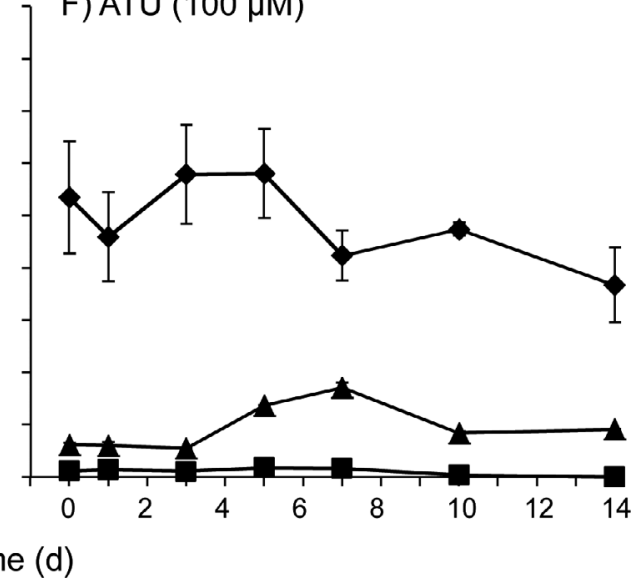

Fig. 2. Nitrification activity of late-July downstream sediment and water samples with the 3 treatments. See Fig. 1 for further details

\section{Urea hydrolysis coupled with ammonia oxidation}

Urea can be degraded to 2 ammonia molecules by microorganisms containing urease genes, including $\mathrm{AOB}$ and AOA. Consequently, urea is a possible organic ammoniacal $\mathrm{N}$ source for $\mathrm{AOB}$ and AOA. The results for the mid-June sediment samples demonstrated that added urea was depleted within
5 d (Fig. 3A). Ammonia concentrations increased transiently, then decreased as ammonia was oxidized, corresponding with $\mathrm{NO}_{2}{ }^{-}+\mathrm{NO}_{3}{ }^{-}$accumulation (Fig. 3A). PTIO-treated downstream sediments also showed that ammonia was generated from urea hydrolysis and sequentially oxidized (Fig. 3B). $\mathrm{NO}_{2}{ }^{-}$ $+\mathrm{NO}_{3}{ }^{-}$productions from these 2 treatments were not significantly different $(p>0.05)$. In the ATU treat- 
Mid-June downstream sediment
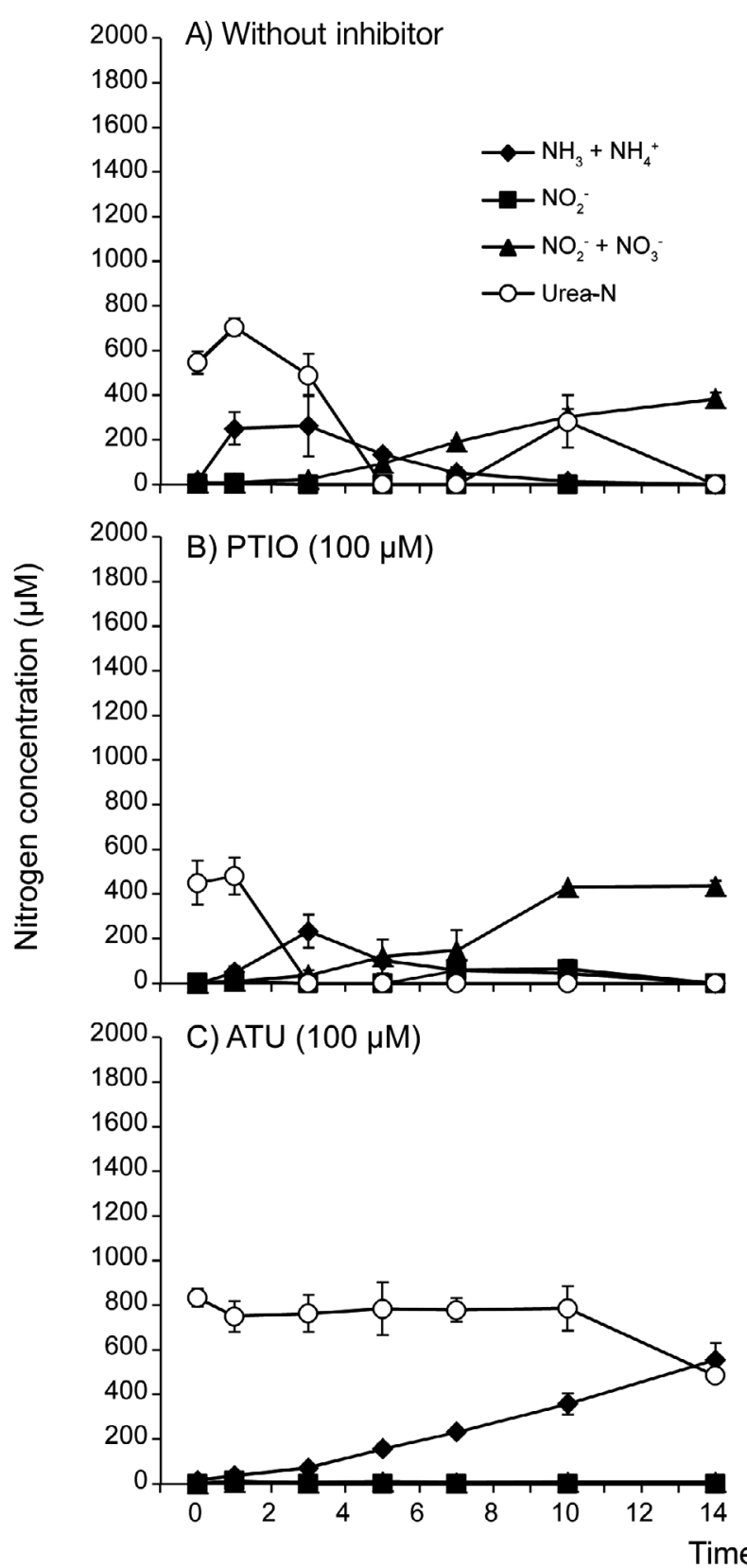

\section{Mid-June downstream water}

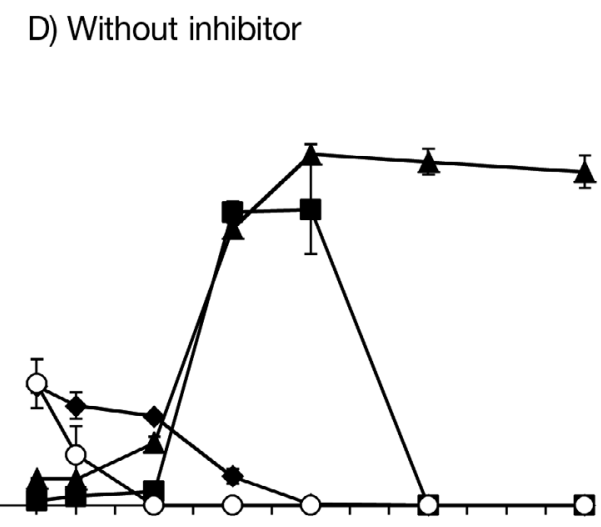

E) PTIO $(100 \mu \mathrm{M})$

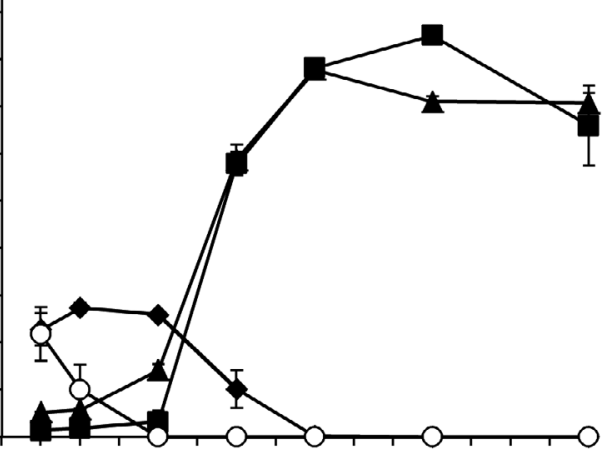

F) ATU $(100 \mu \mathrm{M})$
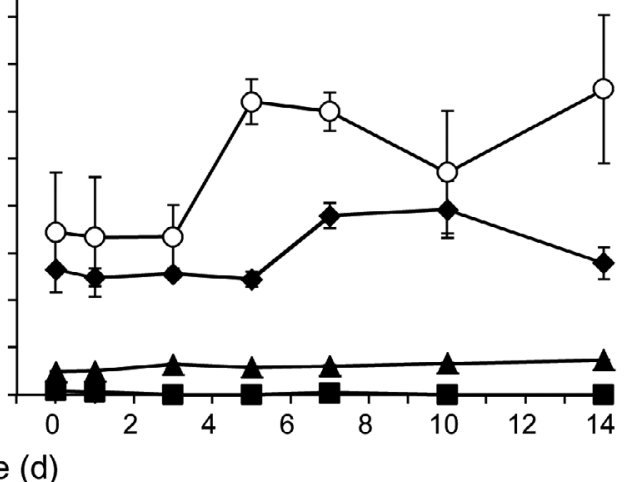

Fig. 3. Urea hydrolysis and nitrification activities of mid-June downstream sediment and water samples with the 3 treatments.

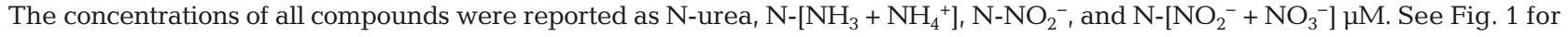
further details

ment, urea was consistent from Days 0 to 10 , and then dropped to $\sim 480 \mu \mathrm{M}$ by Day 14 (Fig. 3C). Ammonia concentrations increased over time; however, no $\mathrm{NO}_{2}{ }^{-}+\mathrm{NO}_{3}{ }^{-}$production was observed, indicating no ammonia oxidation. Potential sources of ammonia include urea hydrolysis and mineralization of sediment-associated cell debris.
The initial ammonia concentration in downstream water was $\sim 560 \mu \mathrm{M}$ (Table 1), whereas the initial ammonia concentration of sediment samples was below the detection limit, due to no ammonia addition to the FWM. Without an inhibitor, the downstream water showed that urea and ammonia were depleted by Days 3 and 7, respectively (Fig. 3D). 
Late-July downstream sediment
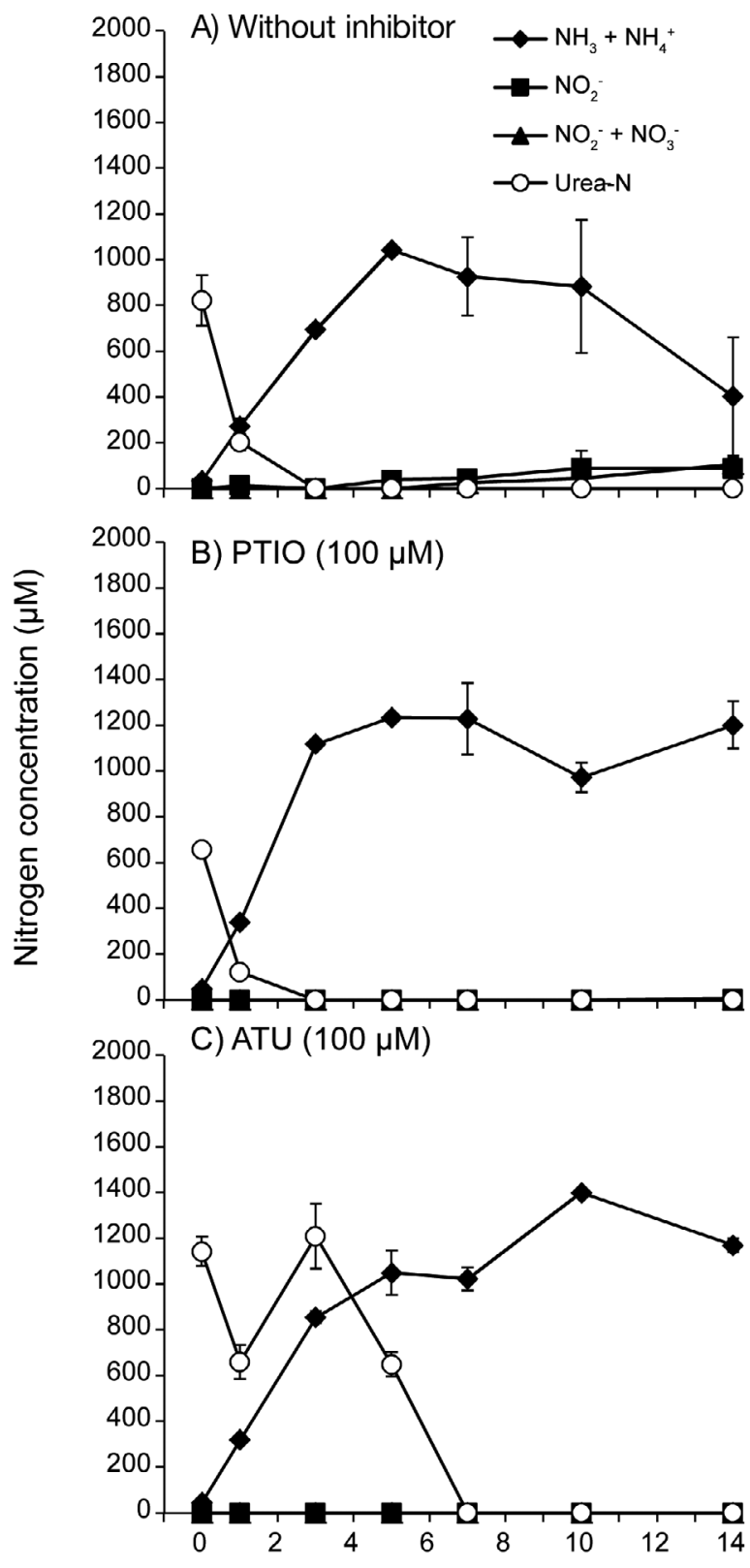

Time $(d)$

\section{Late-July downstream water}

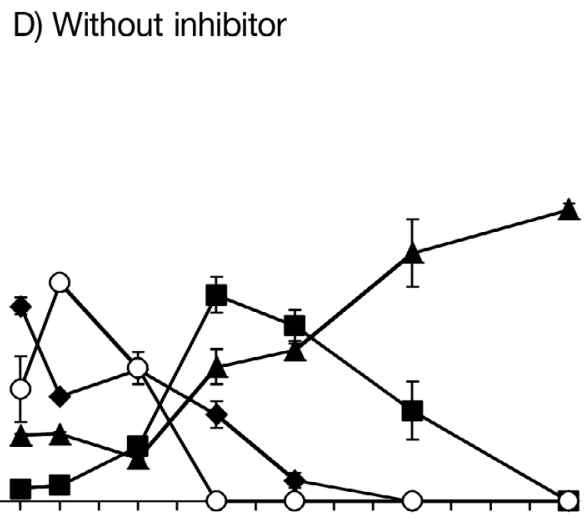

E) PTIO $(100 \mu \mathrm{M})$

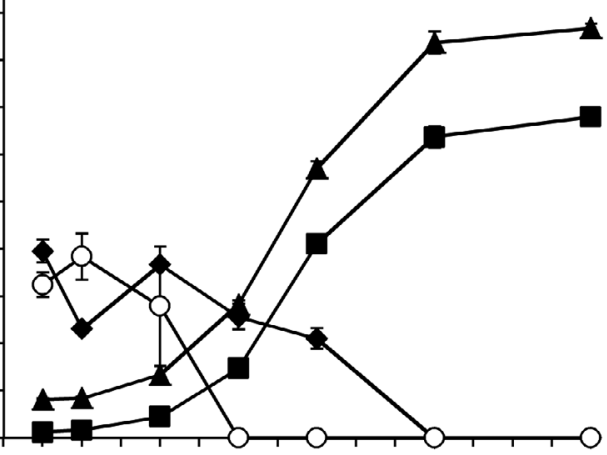

F) ATU $(100 \mu \mathrm{M})$

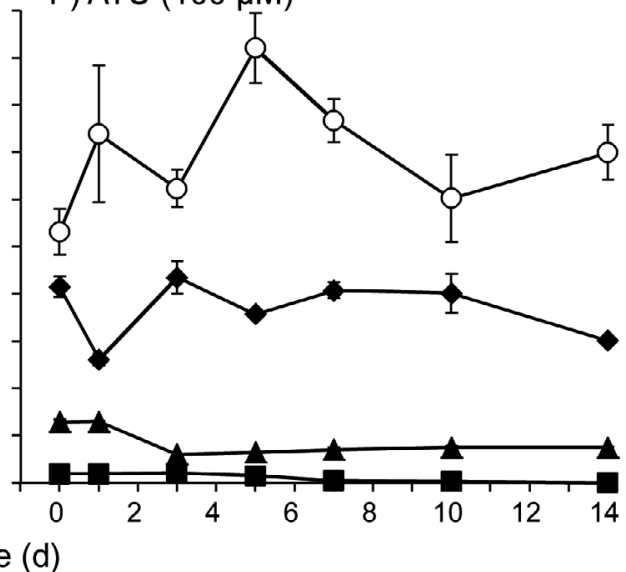

Fig. 4. Urea hydrolysis and nitrification activities of late-July downstream sediment and water samples with the 3 treatments. See Figs. 1 \& 3 for further details

$\mathrm{NO}_{2}{ }^{-}$production increased rapidly from Days 3 to 5 , then subsequently dropped to below detection limits by Day 10. $\mathrm{NO}_{2}{ }^{-}+\mathrm{NO}_{3}{ }^{-}$accumulation was observed between Days 3 to 7 , then remained constant thereafter as $\mathrm{NO}_{2}^{-}$was presumably oxidized to $\mathrm{NO}_{3}{ }^{-}$ (Fig. 3D). PTIO-treated downstream water showed the same trends as the set without an inhibitor, except for the absence of $\mathrm{NO}_{2}{ }^{-}$depletion by Day 10
(Fig. 3E). $\mathrm{NO}_{2}{ }^{-}+\mathrm{NO}_{3}{ }^{-}$productions in these 2 treatments were not significantly different $(p>0.05)$. Nitrification rates of unamended and PTIO-treated downstream water samples were $30.5\left(\mathrm{R}^{2}=0.9\right)$ and $31.8\left(\mathrm{R}^{2}=0.9\right) \mu \mathrm{M} \mathrm{N}-\left[\mathrm{NO}_{2}{ }^{-}+\mathrm{NO}_{3}^{-}\right] \mathrm{ml}^{-1}$ water $\mathrm{d}^{-1}$, respectively. Neither urea hydrolysis nor ammonia oxidation was observed in the ATU treatment, implying that $100 \mu \mathrm{M}$ ATU had the potential to 
inhibit both urea hydrolysis and ammonia oxidation by AOB (Fig. 3F).

As with the ammonia set, the follow-up studies were conducted in late-July. Ammonia produced from urea remained in all downstream sediment treatments (Fig. 4A-C). Urea was completely depleted by Day 3 in the unamended and PTIO treatments, implying that PTIO had no effect on urea hydrolysis. Nevertheless, urea disappeared by Day 7 in the ATU-treated samples. The overall results for the lateJuly and mid-June downstream waters were consistent. However, mid-June samples depleted urea and ammonia faster than the follow-up samples. LateJuly downstream waters in the unamended and PTIO-treated samples showed that urea and ammonia were depleted by Days 5 and 10, respectively (Fig. 4D,E). $\mathrm{NO}_{2}^{-}+\mathrm{NO}_{3}^{-}$accumulated over time in both treatments. $\mathrm{NO}_{2}{ }^{-}+\mathrm{NO}_{3}{ }^{-}$concentrations in these 2 treatments were not significantly different ( $\mathrm{p}>0.05)$. Nitrification rates of late-July unamended and PTIOtreated water samples were $11.5\left(\mathrm{R}^{2}=0.9\right)$ and 21.9 $\left(\mathrm{R}^{2}=1.0\right) \mu \mathrm{M} \mathrm{N}-\left[\mathrm{NO}_{2}^{-}+\mathrm{NO}_{3}^{-}\right] \mathrm{ml}^{-1}$ water $\mathrm{d}^{-1}$, respectively. ATU inhibited both urea hydrolysis and ammonia oxidation in downstream water (Fig. 4F). All negative controls showed no microbial activity (data not shown).

Upstream sediments without an inhibitor and with PTIO addition showed urea depletion, together with increasing ammonia (Fig. S2A,B in the Supplement at www.int-res.com/articles/suppl/a073p151_supp.pdf). The treatment with $100 \mu \mathrm{M}$ ATU was somewhat complicated because a urea spike was observed earlier before decreasing to the expected concentrations ( $\sim 800$ to $\sim 1000 \mu \mathrm{M})$. Urea was relatively constant from Days 3 to 14, whereas ammonia gradually increased and subsequently remained consistent (Fig. S2C). However, the results of upstream waters in all treatments showed neither urea hydrolysis nor ammonia oxidation (Fig. S2D-F). $\mathrm{NO}_{2}{ }^{-}+\mathrm{NO}_{3}{ }^{-}$concentrations of upstream water (Table 1) remained in all treatments and were not significantly different among the 3 treatments ( $p>0.05)$. Urea-N concentration was higher in the upstream water, but undetectable in the downstream water (Table 1), suggesting that urease-positive microorganisms may have transformed urea into ammonia for AOB in downstream samples. All negative controls showed no microbial activity (data not shown).

\section{Relative abundance of $\mathrm{AOB}$ and AOA}

Sediment and water samples from mid-June and late-July were quantified for AOB and AOA 16S rRNA gene abundances. The results showed that although AOA were higher than AOB in sediments, AOB dominated water samples (Fig. 5). Although nitrification activity and urea hydrolysis implicated AOB activity within sediment samples, AOA accounted for $80 \%$ and $57 \%$ of ammonia-oxidizer 16S rRNA genes in midJune and late-July sediments, respectively. In contrast to a dominance of AOA genes in sediment samples, AOB accounted for $\sim 90 \%$ of ammonia-oxidizer $16 \mathrm{~S}$ rRNA genes in both water samples (Fig. 5).

\section{DISCUSSION}

The effective ATU concentration for inhibiting environmental AOB was unclear. Consequently, 2 concentrations (100 and $10 \mu \mathrm{M}$ ) of ATU were applied to both sediment and water samples.

It has been reported that $100 \mu \mathrm{M}$ ATU inhibits $80 \%$ and $85 \%$ of the nitrification rate in marine and soil samples, respectively (Jäntti et al. 2013, LehtovirtaMorley et al. 2013). ATU at $100 \mu \mathrm{M}$ affected both bacterial and archaeal ammonia oxidation in manure compost (Oishi et al. 2012). However, some AOB cultures are highly sensitive to ATU. Nitrosomonas europaea is potentially inhibited by $<10 \mu \mathrm{M}$ ATU (Jung et al. 2011), and the nitrification activity of Nitrosospira multiformis is significantly reduced by $0.4 \mu \mathrm{M}$ ATU (Shen et al. 2013). Our findings demonstrated that ATU at both concentrations effectively

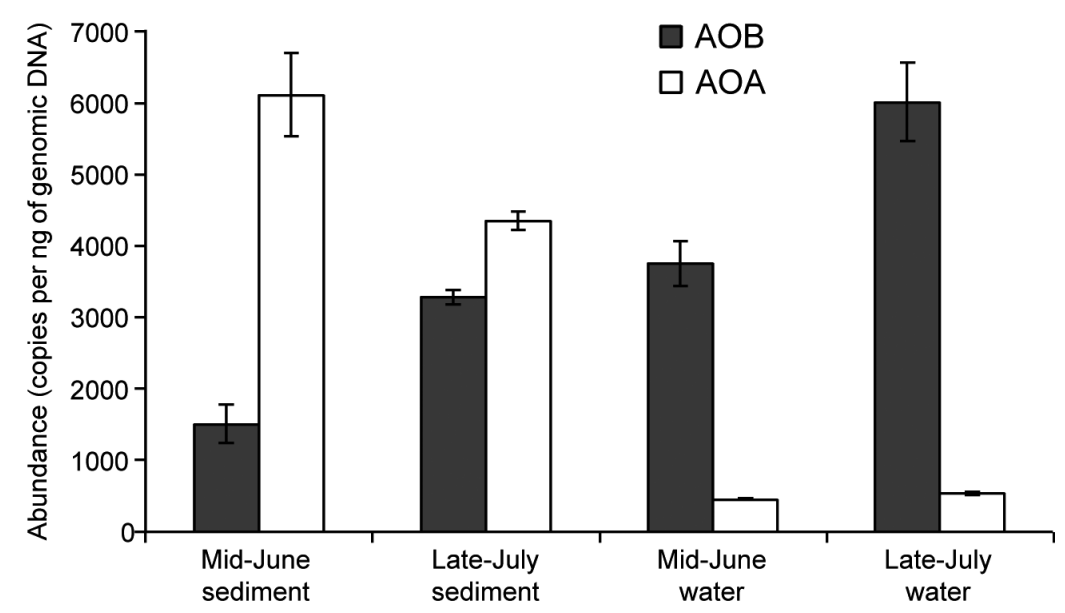

Fig. 5. Relative abundance of ammonia-oxidizing bacteria (AOB) and archaea (AOA) 16S rRNA genes in the sediment and water samples used for assessing nitrification and urea hydrolysis activity. Error bars represent standard deviation of duplicate qPCR amplifications 
inhibited in-river $\mathrm{AOB}$, with less effect on the AOA present in the Grand River.

As for PTIO, $200 \mu \mathrm{M}$ PTIO inhibited AOA without disturbing $\mathrm{AOB}$ in a low-oxygen lab-scale reactor (Yan et al. 2012). An enrichment culture study has shown that $50 \mu \mathrm{M}$ PTIO completely inhibited $\mathrm{NO}_{2}{ }^{-}$ production of $N$. viennensis, whereas $200 \mu \mathrm{M}$ PTIO did not affect $N$. multiformis (Shen et al. 2013). According to our findings, $100 \mu \mathrm{M}$ PTIO showed no effect on $\mathrm{AOB}$ and was likely sufficient for inhibiting AOA in the impacted river. Interestingly, PTIO likely had the potential to inhibit NOB in downstream water in this study. Although PTIO has been reported to inhibit AOA (Yan et al. 2012) and anammox bacteria (Kartal et al. 2011), there has been no information on the effect of PTIO on NOB so far. Future research needs to investigate the modes of action and mechanism of PTIO on nitrite oxidation.

Nitrification rates for unamended and PTIO-treated downstream sediment and water samples were higher than those for ATU-treated samples. In all cases of downstream sediment and water samples, $\mathrm{NO}_{2}{ }^{-}+$ $\mathrm{NO}_{3}{ }^{-}$production rates in unamended and PTIO treatments were significantly higher than those in ATU treatments $(p \leq 0.05)$. Overall, the results suggested that AOB oxidized most of the ammonia from both sediment and water columns impacted by wastewater effluent discharge. High abundances and activities of AOB have been reported previously in ammonia-rich environments, including freshwater (Sonthiphand et al. 2013), marine (Bouskill et al. 2012), and soil (Di et al. 2009). Although the activity of terrestrial AOB has been investigated in many studies, few studies have considered their activity in aquatic environments. AOB activity has been examined in a freshwater ecosystem by using stable isotope probing (Avrahami et al. 2011). The present study is the first study using in vitro nitrification rates with differential inhibitors to confirm AOB dominance in an impacted aquatic environment. Although upstream water showed no ammonia-oxidizing activity in all treatments, the results suggest that $\mathrm{AOB}$ also oxidized ammonia within upstream sediment. Less microbial activity within the upstream sampling site was possibly due to lower biomass and less in situ substrate for microbial activity. Also, the wastewater microbial community showed less impact on the in-river upstream microbial community, possibly resulting in less nitrification activity within upstream samples (Sonthiphand et al. 2013). Potentially viable and active nitrifiers from wastewater effluent might enhance nitrification activity within downstream samples, whereas upstream samples were less impacted by wastewater nitrifiers.
Although the late-July samples show lower nitrification activity than the mid-June samples, differential nitrification inhibitors implied that the ammonia oxidation process was driven primarily by AOB. Nitrification activity is impacted by various environmental factors such as $\mathrm{O}_{2}$ concentration (Triska et al. 1990), temperature (Fdz-Polanco et al. 1994), and organic carbon (Strauss \& Dodds 1997, Strauss \& Lamberti 2000). However, the environmental parameters analyzed in this study were insufficient to correlate with nitrification activity. Consequently, we could not identify the reason for lower nitrification activity in the late-July samples.

Urea hydrolysis was observed in both downstream and upstream sediments; however, ammonia oxidation was inconsistent between mid-June and lateJuly samples. Consequently, it is complicated to relate the co-occurrence of these 2 processes within sediment samples.

The results for downstream water for both time periods suggest that $A O B$ were likely capable of a coupled ammonia oxidation-urea hydrolysis process, reinforcing that $\mathrm{AOB}$ can gain energy from ammonia oxidation to uptake urea for subsequent hydrolysis. Indeed, it has been shown that Nitrosomonas oligotropha has a high urea hydrolysis rate in ammoniasupplemented media (Pommerening-Röser \& Koops 2005). Although AOB were implicated in ammonia oxidation, and possibly also in urea hydrolysis, we could not rule out an important role for additional microorganisms involved in urea hydrolysis that may also be inhibited by ATU. In summary, urea hydrolysis within the effluent-impacted region of the Grand River may be driven by AOB with urease genes, nonnitrifiers with urease genes, or both. Non-nitrifiers with urease genes detected in freshwater are associated with the genera Hydrogenophaga, Acidovorax, Janthinobacterium, and Arthrobacter (Gresham et al. 2007). Our results suggest that $100 \mu \mathrm{M}$ ATU likely slowed and inhibited urea hydrolysis in the downstream sediment and water samples, respectively. However, the mode of action and direct or indirect mechanism of ATU on urease activity needs further investigation.

The relative abundance of AOA was higher than that of $\mathrm{AOB}$ in downstream sediment samples. A higher relative abundance of freshwater AOA has been reported in eutrophic Lake Taihu sediment (China) and shows a negative correlation with organic material (Wu et al. 2010). Although AOA abundance was higher than AOB abundance in our results, their activity might have been inhibited by an accumulation of organic matter within down- 
stream WWTP sediment, just as the growth of Nitrosopumilus maritimus was inhibited by low concentrations of organic compounds (Könneke et al. 2005). Our experimental conditions (i.e. high substrate and neutral $\mathrm{pH}$ ) likely inhibited AOA growth and activity given that AOA play a key role in ammonia oxidation in soils with low nutrient concentrations and a low pH (Gubry-Rangin et al. 2010, Zhang et al. 2012). Also, AOA might use other alternative substrates (i.e. cyanate) for their energy source (Spang et al. 2012). AOA found in a petroleum refinery WWTP are likely not chemolithoautotrophs; they possibly use hydrocabons or other unknown substances for energy and carbon (Mußmann et al. 2011). Another possible reason for high abundance but less activity might be an accumulation of AOA cell debris in sediment samples that are detected by DNA-based analyses. In contrast to downstream sediment samples, AOB 16S rRNA genes were higher than AOA 16S rRNA genes in downstream water samples. These results are consistent with a strong dominance of AOB activity in downstream water columns and consistent with previous research showing that wastewater effluent can enhance nitrification activity and AOB abundance in receiving waters (Mußmann et al. 2013).

\section{CONCLUSIONS}

AOB are important microorganisms for in-river biogeochemical cycling, and are implicated in ammonia oxidation in effluent-impacted Grand River samples. Added PTIO had no effect on in-river ammonia oxidation, but ATU completely inhibited bacterial ammonia oxidation. AOB within downstream water likely have the ability to oxidize ammonia and hydrolyze urea, indicating that ammonia produced by urea is an alternative $\mathrm{N}$ source for $\mathrm{AOB}$. Modes of action and direct or indirect mechanisms of PTIO and ATU on urease and nitrite-oxidizing activities require further investigation. Molecular analysis confirmed the activity of AOB within this impacted water column. Our findings implicate AOB as dominant microbial players for both ammonia oxidation and urea hydrolysis within the Grand River.

Acknowledgements. We thank Eduardo Cejudo for his assistance during the sampling trips as well as Barbara J. Butler and Laura A. Sauder for constructive comments. This research was supported by a Strategic Projects Grant from the National Science and Engineering Research Council of Canada (NSERC).

\section{LITERATURE CITED}

Avrahami S, Jia Z, Neufeld JD, Murrell JC, Conrad R, Kusel K (2011) Active autotrophic ammonia-oxidizing bacteria in biofilm enrichments from simulated creek ecosystems at two ammonium concentrations respond to temperature manipulation. Appl Environ Microbiol 77:7329-7338

Bédard C, Knowles R (1989) Physiology, biochemistry, and specific inhibitors of $\mathrm{CH}_{4}, \mathrm{NH}_{4}{ }^{+}$, and $\mathrm{CO}$ oxidation by methanotrophs and nitrifiers. Microbiol Rev 53:68-84

Bouskill NJ, Eveillard D, Chien D, Jayakumar A, Ward BB (2012) Environmental factors determining ammoniaoxidizing organism distribution and diversity in marine environments. Environ Microbiol 14:714-729

> Di HJ, Cameron KC (2011) Inhibition of ammonium oxidation by a liquid formulation of 3,4-dimethylpyrazole phosphate (DMPP) compared with a dicyandiamide (DCD) solution in six New Zealand grazed grassland soils. J Soils Sediments 11:1032-1039

> Di HJ, Cameron KC, Shen JP, Winefield CS, O'Callaghan M, Bowatte S, He JZ (2009) Nitrification driven by bacteria and not archaea in nitrogen-rich grassland soils. Nat Geosci 2:621-624

Fdz-Polanco F, Villaverde S, Garcia P (1994) Temperature effect on nitrifying bacteria activity in biofilters: activation and free ammonia inhibition. Water Sci Technol 30: 121-130

> Gresham TL, Sheridan PP, Watwood ME, Fujita Y, Colwell FS (2007) Design and validation of ureC-based primers for groundwater detection of urea-hydrolyzing bacteria. Geomicrobiol J 24:353-364

> Gubry-Rangin C, Nicol GW, Prosser JI (2010) Archaea rather than bacteria control nitrification in two agricultural acidic soils. FEMS Microbiol Ecol 74:566-574

> Hallam SJ, Mincer TJ, Schleper C, Preston CM, Roberts K, Richardson PM, DeLong EF (2006) Pathways of carbon assimilation and ammonia oxidation suggested by environmental genomic analyses of marine Crenarchaeota. PLoS Biol 4:e95

> Jäntti H, Jokinen S, Hietanen S (2013) Effect of nitrification inhibitors on the Baltic Sea ammonia-oxidizing community and precision of the denitrifier method. Aquat Microb Ecol 70:181-186

Jia Z, Conrad R (2009) Bacteria rather than archaea dominate microbial ammonia oxidation in an agricultural soil. Environ Microbiol 11:1658-1671

Jung MY, Park SJ, Min D, Kim JS and others (2011) Enrichment and characterization of an autotrophic ammoniaoxidizing archaeon of mesophilic crenarchaeal groupI.1a from an agricultural soil. Appl Environ Microbiol 77: 8635-8647

Kartal B, Maalcke WJ, de Almeida NM, Cirpus I and others (2011) Molecular mechanism of anaerobic ammonium oxidation. Nature 479:127-130

> Kemp MJ, Dodds WK (2002) Comparisons of nitrification and denitrification in prairie and agriculturally influenced streams. Ecol Appl 12:998-1009

> Könneke M, Bernhard AE, de la Torre JR, Walker CB, Waterbury JB, Stahl DA (2005) Isolation of an autotrophic ammonia-oxidizing marine archaeon. Nature 437: 543-546

Kowalchuk GA, Stephen JR, De Boer W, Prosser JI, Embley TM, Woldendorp JM (1997) Analysis of ammonia-oxidizing bacteria of the $\beta$ subdivision of the class Proteobacteria in costal sand dunes by denaturing gradient gel elec- 
trophoresis and sequencing of PCR-amplified 16S ribosomal DNA fragments. Appl Environ Microbiol 63: 1489-1497

Lehtovirta-Morley LE, Verhamme DT, Nicol GW, Prosser JI (2013) Effect of nitrification inhibitors on the growth and activity of Nitrosotalea devanaterra in culture and soil. Soil Biol Biochem 62:129-133

- Miranda KM, Espey MG, Wink DA (2001) A rapid, simple spectrophotometric method for simultaneous detection of nitrate and nitrite. Nitric Oxide 5:62-71

Mosier AC, Allen EE, Kim M, Ferriera S, Francis CA (2012) Genome sequence of 'Candidatus Nitrosopumilus salaria' BD31, an ammonia-oxidizing archaeon from the San Francisco Bay estuary. J Bacteriol 194:2121-2122

> Mußmann M, Brito I, Pitcher A, Damsté JSS and others (2011) Thaumarchaeotes abundant in refinery nitrifying sludges express amoA but are not obligate autotrophic ammonia oxidizers. Proc Natl Acad Sci USA 108: 16771-16776

> Mußmann M, Ribot M, von Schiller D, Merbt SN and others (2013) Colonization of freshwater biofilms by nitrifying bacteria from activated sludge. FEMS Microbiol Ecol 85: 104-115

O'Callaghan M, Gerard EM, Carter PE, Lardner R and others (2010) Effect of the nitrification inhibitor dicyandiamide (DCD) on microbial communities in a pasture soil amended with bovine urine. Soil Biol Biochem 42: $1425-1436$

Ochsenreiter T, Selezi D, Quaiser A, Bonch-Osmolovskaya L, Schleper C (2003) Diversity and abundance of Crenarchaeota in terrestrial habitats studied by 16S RNA surveys and real time PCR. Environ Microbiol 5:787-797

> Oishi R, Tada C, Asano R, Yamamoto N, Suyama Y, Nakai Y (2012) Growth of ammonia-oxidizing archaea and bacteria in cattle manure compost under various temperatures and ammonia concentrations. Microb Ecol 63:787-793

> Pommerening-Röser A, Koops HP (2005) Environmental pH as an important factor for the distribution of urease positive ammonia-oxidizing bacteria. Microbiol Res 160: 27-35

Poulin P, Pelletier E (2007) Determination of ammonium using a microplate-based fluorometric technique. Talanta 71:1500-1506

Rysgaard S, Thastum P, Dalsgaard T, Christensen PB, Sloth NP (1999) Effects of salinity on $\mathrm{NH}_{4}{ }^{+}$adsorption capacity, nitrification, and denitrification in Danish estuarine sediments. Estuaries 22:21-30

Santoro AE, Casciotti KL (2011) Enrichment and characterization of ammonia-oxidizing archaea from the open ocean: phylogeny, physiology and stable isotope fractionation. ISME J 5:1796-1808

Shen T, Stieglmeier M, Dai J, Urich T, Schleper C (2013) Responses of the terrestrial ammonia-oxidizing archaeon Ca. Nitrososphaera viennensis and the ammonia-oxidizing bacterium Nitrosospira multiformis to nitrification inhibitors. FEMS Microbiol Lett 344:121-129

Simon N, Kennedy M (1987) The distribution of nitrogen species and adsorption of ammonium in sediments from the tidal Potomac River and estuary. Estuar Coast Shelf Sci 25:11-26

Sonthiphand P, Cejudo E, Schiff SL, Neufeld JD (2013) Wastewater effluent impacts ammonia-oxidizing pro-

Editorial responsibility: Tom Battin,

Vienna, Austria karyotes of the Grand River, Canada. Appl Environ Microbiol 79:7454-7465

Spang A, Poehlein A, Offre P, Zumbrägel S and others (2012) The genome of the ammonia-oxidizing Candidatus Nitrososphaera gargensis: insights into metabolic versatility and environmental adaptations. Environ Microbiol 14:3122-3145

Strauss EA, Dodds W (1997) Influence of protozoa and nutrient availability on nitrification rates in subsurface sediments. Microb Ecol 34:155-165

Strauss EA, Lamberti GA (2000) Regulation of nitrification in aquatic sediments by organic carbon. Limnol Oceanogr 45:1854-1859

- Taylor AE, Zeglin LH, Dooley S, Myrold DD, Bottomley PJ (2010) Evidence for different contributions of archaea and bacteria to the ammonia-oxidizing potential of diverse Oregon soils. Appl Environ Microbiol 76: 7691-7698

- Thamdrup B (2012) New pathways and processes in the global nitrogen cycle. Annu Rev Ecol Syst 43:407-428

Tourna M, Stieglmeier M, Spang A, Könneke M and others (2011) Nitrososphaera viennensis, an ammonia oxidizing archaeon from soil. Proc Natl Acad Sci USA 108: 8420-8425

Triska FJ, Duff JH, Avanzino RJ (1990) Influence of exchange flow between the channel and hyporheic zone on nitrate production in a small mountain stream. Can J Fish Aquat Sci 47:2099-2111

Voytek MA, Ward BB (1995) Detection of ammoniumoxidizing bacteria of the beta-subclass of the class Proteobacteria in aquatic samples with the PCR. Appl Environ Microbiol 61:1444-1450

> Walker CB, de la Torre JR, Klotz MG, Urakawa H and others (2010) Nitrosopumilus maritimus genome reveals unique mechanisms for nitrification and autotrophy in globally distributed marine crenarchaea. Proc Natl Acad Sci USA 107:8818-8823

> Wu Y, Xiang Y, Wang J, Zhong J, He J, Wu QL (2010) Heterogeneity of archaeal and bacterial ammonia-oxidizing communities in Lake Taihu, China. Environ Microbiol Rep 2:569-576

> Xia W, Zhang C, Zeng X, Feng Y and others (2011) Autotrophic growth of nitrifying community in an agricultural soil. ISME J 5:1226-1236

> Yan J, Haaijer SC, Op den Camp HJ, van Niftrik L and others (2012) Mimicking the oxygen minimum zones: stimulating interaction of aerobic archaeal and anaerobic bacterial ammonia oxidizers in a laboratory-scale model system. Environ Microbiol 14:3146-3158

Zawada RJX, Kwan P, Olszewski KL, Llinas M, Huang SG (2009) Quantitative determination of urea concentrations in cell culture medium. Biochem Cell Biol 87:541-544

Zhalnina K, de Quadros PD, Camargo FA, Triplett EW (2012) Drivers of archaeal ammonia-oxidizing communities in soil. Front Microbiol 3:210

> Zhang LM, Offre PR, He JZ, Verhamme DT, Nicol GW, Prosser JI (2010) Autotrophic ammonia oxidation by soil thaumarchaea. Proc Natl Acad Sci USA 107:17240-17245

Zhang LM, Hu HW, Shen JP, He JZ (2012) Ammonia-oxidizing archaea have more important role than ammoniaoxidizing bacteria in ammonia oxidation of strongly acidic soils. ISME J 6:1032-1045

Submitted: January 31, 2014; Accepted: July 3, 2014

Proofs received from author(s): August 22, 2014 